\title{
HISTORY OF PSYCHIATRY AND MENTAL HEALTH IN EL SALVADOR. A PERSPECTIVE OF PUBLIC HEALTH, SOCIAL SECURITY AND PRIVATE PRACTICE
}

Dr. Francisco Antonio Araniva Garcia. Instituto Salvadoreño del Seguro Social. San Salvador, El Salvador; Salvadoran

Psychiatric Association, San Salvador, El Salvador.
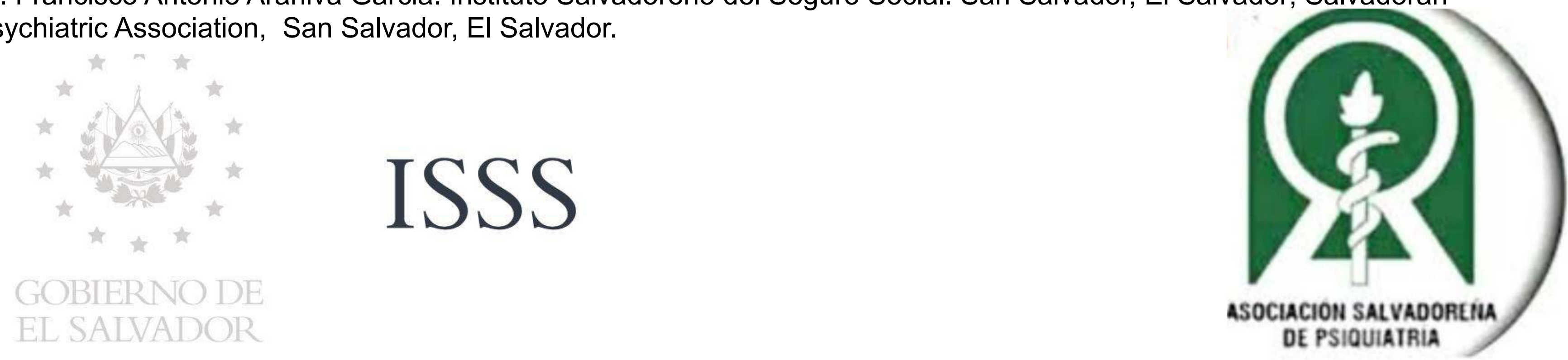

ISSS

ASP

\begin{abstract}
Objectives:
To describe the history of psychiatry in El Salvador.

To analyze from a historical perspective the psychiatry as a speciality of medicine in El Salvador.

To compare the historical development of psychiatry in El

Salvador in the field of public health, social security and private practice.

To describe the history of the Salvadoran Psychiatric Association and those who have been its presidents.
\end{abstract}

\section{Background: \\ El Salvador is the smallest country of the continental America, and have only two psychiatrist hospital: One is part of the national public health system and the other one is part of the social security network. In the past there were private hospitals of psychiatry, none at this time (March 2019) but in El Salvador many psychiatrist has private practice.}

\section{Materials and Methods:}

A systematic review was made of books of the history of psychiatry in El Salvador and news in the national newspaper library.

\section{Results and Conclusions:}

It is a systematic description of the history of psychiatry in El Salvador that reveals the presence of psychiatry since the beginning of the republic period.

Since the year 1880 in the factulty of medicine at the University of El Salvador have been theses related to psychiatry and mental health issues.

The presence of Salvadoran Psychiatric Association since the year of 1976.

Since the year of 1983 the Salvadoran Psychiatric Association its part of the World Psychiatric Association.

The first private hospital of psychiatry in El Salvador was founded in 1965 .

Thorughout history since 1977, 16 salvadoran psychiatrists have been presidents of the Salvadoran Psychiatric Association.

\section{References}

1. Escalante, C.A. Inicios y cursos de la psiquiatría y la salud mental en El Salvador. In: González, V.G (ed.) La Psiquiatría y la Salud Mental en EI Salvador. El Salvador: ; 2010. p. 167-213.

2. Rauda, M. El Hospital Santa Sofía. In: Rauda, M (ed.) El Alma Salvadoreña vista por un psiquiatra. El Salvador: Asociación Institución Salesiana; 2007. p. $89-112$.

Copyright @ Dr. Francisco Araniva. Email: franciscoaraniva@gmail.com Adress: Apartado Postal 1489, Centro de Gobierno. San Salvador, El Salvador.
The first National Psychiatric Hospital in El Salvador was founded December 14th 1894.

In the Social Security System, the first hospital was founded in the year of 1971.

In the private practice the first hospital was founded August 8th 1965, the name of the hospital was: Hospital Santa Sofía, at the beginning the hospital was called: Clínica Hogar.

\begin{tabular}{ll}
$\begin{array}{l}\text { Presidents of the Salvadoran Psychiatric Association } \\
\text { Years }\end{array}$ & \multicolumn{1}{c}{ Name } \\
$1977-1978$ & Dr. Ricardo Adonai Girón \\
$1978-1979$ & Dr. Antonio Argueta Cordón \\
$1979-1981$ & Dr. Mauricio Salazar \\
$1981-1982$ & Dr. Guido Arias Bojórquez \\
$1982-1984$ & Dr. Carlos A. Escalante \\
$1984-1985$ & Dr. Mauricio Salazar \\
$1985-1988$ & Dr. Víctor Guillermo González \\
$1988-1991$ & Dr. Francisco A. Paniagua \\
$1991-1993$ & Dr. Claudina de Campos \\
$1993-1998$ & Dr. Manuel U. Mejía Peña \\
$1998-2000$ & Dr. Otto Moisés Castro \\
$2000-2004$ & Dr. José Miguel Fortín Magaña \\
$2004-2006$. & Dr.Otto Moisés Castro \\
$2006-2008$ & Dr. Gerardo Rivera Trejo \\
$2008-2010$. & Dr. Claudia Barahona \\
$2010-2012$ & Dr. José Miguel Fortín Magaña \\
$2012-2016$ & Dra. Tirza Merino Gómez \\
$2016-2019$ & Dra. Claudina de Campos \\
$2019-$ & Dr. Mario Flores
\end{tabular}

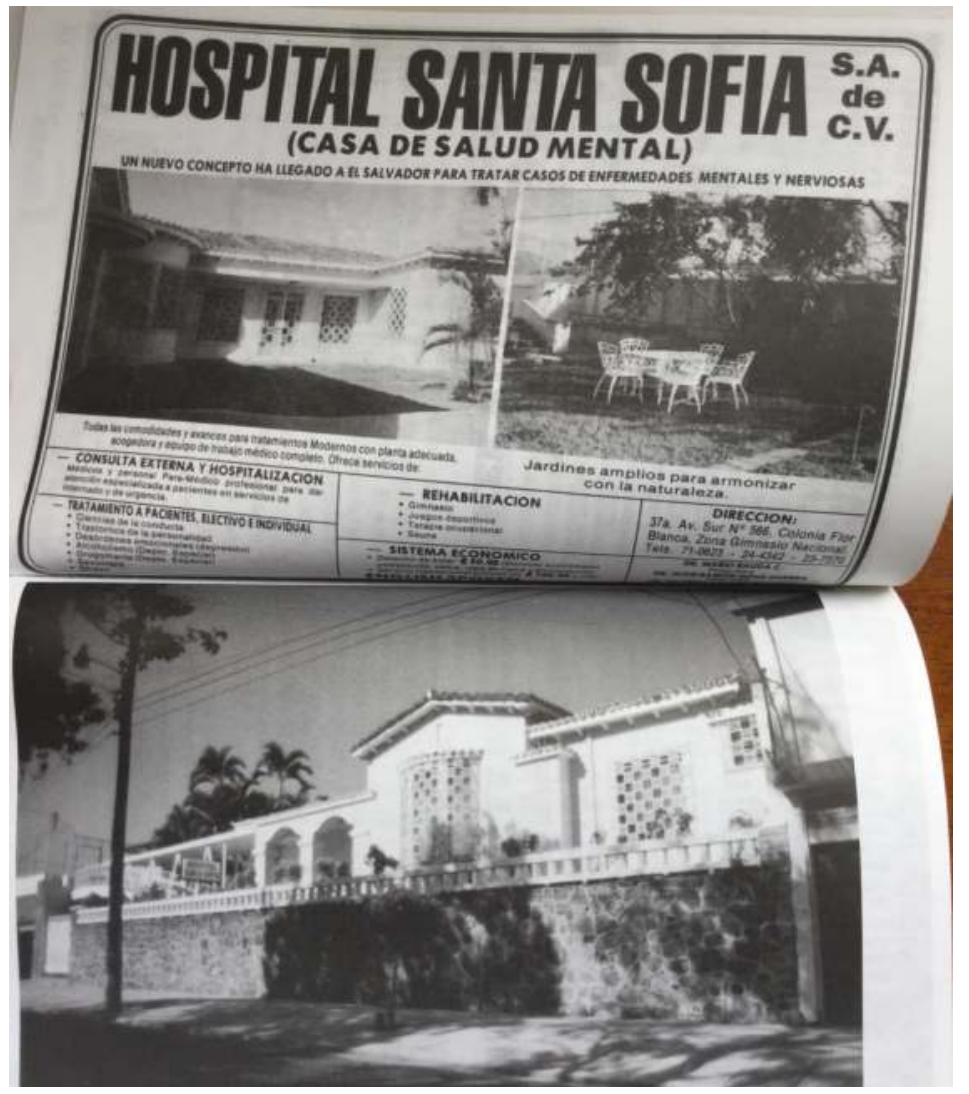

First private hospital in El Salvador. Year: 1965 